\title{
4
}

\section{Reflecting on the philosophical implications of evolution}

\author{
I.H. Horn
}

Dept. Primary School Teacher Education

University of South Africa

PRETORIA

E-mail: hornih@unisa.ac.za

\section{Abstract}

Reflecting on the philosophical implications of evolution

Evolution as paradigm is a prescribed topic in contemporary South African education. This means that macro-evolution - the idea that life evolved progressively from inert matter to humankind's coming into being - must form the foundation of South African education. The aim of this article is to reflect, in a spirit of respectful yet critical enquiry, on three issues with regard to macro-evolution: First, the theory of macro-evolution is placed in its historical context which indicates that although this theory owes its widespread acceptance to Charles Darwin, it did not originate with him. Second, the scientific status of the theory of macro-evolution is scrutinised. Karl Popper's view of this theory as a metaphysical framework for research is given, accompanied by a brief discussion. Third, three evolutionary worldviews are identified and discussed.

\section{Opsomming}

'n Besinning oor die filosofiese implikasies van evolusie

Evolusie as paradigma word tans vir Suid-Afrikaanse onderwys voorgeskryf. Dit beteken dat makroevolusie - die idee dat lewe progressief vanaf nie-lewende materie tot by die mens opwaarts ontwikkel het - die grondslag van die Suid-Afrikaanse onderwys moet vorm. Die doel met hierdie artikel is om in 'n gees van respekvolle dog kritiese vraagstelling oor drie sake wat op makroevolusie betrekking het, na te dink: Eerstens word die teorie van makroevolusie in sy historiese konteks geplaas wat daarop dui dat die wye aanvaarding van dié teorie wel aan Charles Darwin te danke is, maar dat dit nie by hom onstaan het nie. Tweedens word die wetenskaplike status van die teorie van makroevolusie onder oë geneem. Karl Popper se siening van dié teorie as 'n metafisiese navorsingsraamwerk word gegee en toegelig met 'n oorsigtelike bespreking. Derdens word drie evolusionêre wêreldbeskouings geïdentifiseer en bespreek. 


\section{Introduction}

In June 2000 the Human Sciences Research Council (HSRC) convened a colloquium on science and evolution at which Dr. Jeffrey Lever, a consultant to the HSRC's Africa Human Genome Initiative, called for evolution as a paradigm for education. Education Minister Kader Asmal agreed with this call (Gosling, 2000). South African education will thus henceforth be embedded in the theory and paradigm of evolution - a given that makes a study of its philosophical worldview implications imperative. This article will therefore consider the following:

- the historical roots of the theory of evolution

- the philosophic-scientific status of the theory of evolution

- possible evolutionary worldviews

\section{Clarification of the term "evolution"}

Throughout this article the term "evolution" refers to macro-evolution and not to microevolution. Microevolution is the observable and demonstrable evolutionary variations within a species lineage that occur both in nature and in the laboratory when a new breed of a plant or an animal species is bred, for example, a new rose or a new dog species (Hoover, 1988:16). Microevolution is the result of the "amazing machinery within the [living] cell capable of shuffling and recombining genetic information" (Ackerman \& Williams, 1999:51). Microevolution should be taught - adaptation, natural selection, mutations, genetic drift, Mendelian genetics and DNA structure and variability. Unlike microevolution, macro-evolution has never been observed. Macro-evolution is a hypothetical extrapolation from microevolution. It is a theory of origins which posits that all the myriad forms of life evolved progressively from inert matter to humankind's coming into being.

\section{The historical roots of the theory of evolution}

\section{Macro-evolution and Darwin}

Macro-evolution owes its widespread acceptance to Charles Darwin (1809-1882) but it did not originate with him (Sunderland, 1988:13). Macro-evolutionary ideas can be traced in the ancient philosophies of the Chinese, Hindu, Egyptian, Assyrian and Greek nations. In ancient Greek thought the first name mentioned to elucidate a theory of origins involving a progressive evolution from simple elements into plants, then animals and finally into humans was Thales of Miletus (640-546 BC) (Sunderland, 1988:13). These early theories revolved around the idea of the spontaneous generation of life from nothing or from nonliving matter (Goertz, 
1990:5; Sunderland, 1988:13). For example, Aristotle believed that maggots and flies were generated from rotting flesh and slime (Goertz, 1990:234), the Egyptians believed that frogs were spontaneously generated after the Nile had flooded (Sunderland, 1988:13) and the Chinese and medieval Europeans believed that insects developed from nothing on plants (Goertz, 1990:234-235; Sunderland, 1988:13).

\section{The chain of being}

Although Europe in its time of domination by the Roman Church paid nominal allegiance to biblical creationism (Morris, 1989:199), evolutionary concepts were handed down through ancient Greek philosophers such as Plato and Aristotle (Sunderland, 1988:13). Western thought also inherited from the ancient Greeks the idea of a great chain of being (hierarchy of living earthly beings). Prior to Darwin the great chain of being was conceived of as a static, hierarchical structure ranging from the lowest, simplest form of life to the highest, most complex form of life. At the bottom of the great chain was inanimate matter and at the top was God. This scheme was especially popular during the Middle Ages till the late eighteenth century (Lovejoy, 1942:59). This schema was regarded as a metaphysical principle, a plan emanating from the mind of God (Morris, 1989:185; Stromberg, 1966:274).

After Darwin the great chain of being was conceived of as an evolutionary structure. The evolutionist and historian of evolutionary thought, Loren Eiseley (cited in Morris, 1989:185), maintains that "All that the Chain of being actually needed to become a full-fledged evolutionary theory was the introduction into it of the conception of time in vast quantities added to mutability of form". The vast amount of time was supplied by geological uniformitarianism. In contrast to catastrophism which ascribes geological and fossil formation mainly to past catastrophic events (earthquakes, volcanic eruptions, climatic changes, floods or impacts of extraterrestrial bodies) uniformitarianism or gradualism explains geological and fossil formation by assuming the steady, unchanging operation of natural forces over immensely long periods of time. The mechanism for the mutability of form was supplied by Charles Darwin's hypothesis of natural selection or the survival of the fittest.

\section{Modern biological evolutionists}

Before Darwin there had been other modern biological evolutionists. Among these were Benoit de Maillet (1656-1738), Pierre de Maupertuis (1698-1759), Comte de Buffon (1707-1788), Charles Darwin's grandfather Erasmus Darwin (1731-1802) and Jean Baptiste de Lamarck (1744-1829). According to the historian, Benjamin Farrington (cited in Sunderland, 1988:15), Darwin did not acknowledge the previous 
contributions to his theory nor that natural selection had been used by the theologian, William Paley, (1743-1805) and the nineteenth-century scientist, Edward Blyth, who argued that only the fittest survived in order to preserve the created type. In articles published in 1835 and 1837 Blyth presented the idea of natural selection of which Darwin claimed to be the originator. Blyth's conclusion was that the survival of the strongest in a species was a conservative principle which enabled the transmission of superior qualities to offspring and thereby secured the survival of the species (Sunderland, 1988:16; Morris, 1989:157-158).

With regard to the theologian, William Paley, Farrington writes that Darwin was familiar with Paley's book of 1802, Natural theology or evidence of the existence and attributes of the Deity collected from the appearances of nature, and "found his logic as cogent as that of Euclid" (Sunderland, 1988:15). It was therefore not weak or erroneous argumentation on Paley's part that led Darwin to reject Paley's (and Blyth's) view that natural selection speaks of phylic stability and to posit instead natural selection as the mechanism for evolution from lower species to new, higher species. Paley and Darwin had different metaphysical beliefs. Paley was a theist and the chief burden of his book "was that all nature speaks of the Designer behind it" (Wilder-Smith, 1981a:229). Darwin was an agnostic (Brown, 1968:149; Stromberg, 1966:279) and he "attempted to explain the origination of the great diversity of life without the necessity of any divine power" (Sunderland, 1988:16). Wilder-Smith (1981a:230) points out that one of Darwin's central theses was the illogical claim "that design by no means proved a designer behind it".

\section{Darwin's theory}

Darwin's theory rapidly gained popularity, which can be ascribed to the secular intellectual climate that the eighteenth-century Enlightenment had engendered. When Darwin published The origin of species by means of natural selection or the preservation of favoured races in the struggle for life in 1859, "people were in the mood to hail it as what seemed to be the first totally acceptable explanation for the origin and development of living things" (Frair \& Davis, 1983:12). From the observed evidence of microevolutionary changes within a species, namely adaptation and natural selection, Darwin drew the conclusion that radical changes in phylic form have occurred in the past and led to the variety and complexity of life forms as they are known today (Wilder-Smith, 1981a:24). Darwin did not address the origin of the first living system, but macro-evolution includes the idea that the first life evolved from inert matter. 
At this stage it is appropriate to explore how Karl Popper, twentiethcentury's foremost philosopher of science, classifies the theory of macroevolution.

\section{The philosophical-scientific status of the theory of evolution}

\section{Karl Popper's views}

Karl Popper himself is an evolutionist, but he says the following about Darwin's theory:

I have come to the conclusion that Darwinism [by extension, any theory on origins] is not a testable scientific theory, but a metaphysical research programme [emphasis mine] - a possible framework for testable scientific theories. It suggests the existence of a mechanism of adaptation ... This is of course the reason why Darwinism has been almost universally accepted. Its theory of adaptation was the first nontheistic one that was convincing; and theism was worse than an open admission of failure, for it created the impression that an ultimate explanation had been reached (cited in Sunderland, 1988:28; italics Sunderland).

In other words, Popper classifies the theory of evolution - macroevolution - as a paradigm which science can use to account for the variety of living things and he ascribes its widespread acceptance to its nontheistic explanation of phylic variation. Popper classifies macroevolutionary theory as a metaphysical paradigm because it is not falsifiable. Popper's best known contribution to the philosophy of science was that he recognised that to be scientific a theory must in principle be falsifiable. A theory is good if it could very easily be falsified, and when it consistently survives all tests, it is accepted as a valid theory (Cloete, 2000:41; Gitt,1997:24, note 3).

Macro-evolution deals with unique events. Even a laboratory simulation of such an event would not conclusively prove that the original event occurred in the same way. Scientists do of course cite facts and observations in support of macro-evolution, and one does not contest such facts. However, the explanatory theories, that is the conclusions scientists draw from facts and observations, are not as a matter of course true (Wilder-Smith, 1975:32). Theories must be experimentally tested, but

the only aspect of his [Darwin's] theory which has received any support over the past century is where it applies to microevolutionary processes. His general theory that all life on earth originated by a gradual successive accumulation of fortuitous mutations, is still, as it was in Darwin's time, a highly speculative hypothesis entirely without direct 
factual support and very far from that self-evident axiom some of its more aggressive advocates would have us believe (Denton, 1987:77, see also 345).

The crucial evidence of an intermediate, transitional fossil is still lacking (Brand, 1997:172 ff; Denton, 1987:162 ff; Holbrook, 1987:147-149, 208; Parker, 1987:128 ff; Sunderland, 1988:69 ff, $98 \mathrm{ff}$ ) and claims, usually of an ape-to-human transition, deserve serious consideration but not a tooready, uncritical acceptance (Parker, 1987:160). Macro-evolution would require that the cell produces new genetic information, but molecular biologists have found that this cannot be done. Natural selection, genetic drift and laboratory-manipulation shuffle or deplete genetic information but do not add new information to the existing genetic code (Ackerman \& Williams, 1999:51). With regard to the generation of life from inert matter, already in1864 Louis Pasteur's "swan-neck jar" experiments proved that biogenesis does not occur without mediation of previously existing life (as a canning factory also proves) (Goertz, 1990:6; Wilder-Smith, 1981a: 23, 1981b:viii-ix).

\section{Macro-evolutionary theory: flaws and illogicalities}

The examination of macro-evolutionary theory reveals "flaws, illogicalities, non-sequiters" (Holbrook,1987:9) and some evolutionists have admitted that there are facts that are ignored and that the theory is altered to fit selected data (Klein, 1988:5). Nevertheless, the theory could be true, and scientists may discover how to synthesise aspects of macroevolution, for example, creating life from nonlife. Molecular biology has revealed that the creation of a new living system requires the physical elements (building blocks), energy (power), the pertinent information (design or blueprint which at present is only accessible to scientists via existing living systems) and processes which guarantee the correct, orderly use of the information (Mohr, 1989:146). At present scientists do not know what these processes are and whether natural laws govern their functioning. Scientists can therefore at present only create life from existing living systems. However, finding and applying the relevant natural laws, if they exist, and thereby creating life from nonlife in the laboratory cannot be ruled out, but it would not prove macro-evolution. It would not be the natural laws that created the new living system, but the application of the laws by the intelligent mind of the scientist (WilderSmith, 1974:92-93; 1975:32-35; 1981a:25 ff).

The origin of the first living system is scientifically untestable, and acceptance or rejection of any explanatory theory is ultimately a matter of faith. Faith, not scientific evidence, is reflected in the biochemist Ernest Kahane's statement: "Its absurd and absolutely preposterous to believe that a living cell could come into existence by itself; but, notwithstanding, 
I do believe it, because I cannot imagine anything else" (cited in Gitt, 1993:13-14).

The fact that macro-evolution is a metaphysical and not a scientific theory is of course no reason for not embedding education in an evolutionary paradigm, but only if its philosophical, worldview implications are not an infringement of a student's constitutional right to freedom of belief. In the next section these implications will be scrutinised.

\section{Evolutionary worldviews}

The physicist and social critic Fritjof Capra (1990:105) points out that Darwin's theory "forced scientists to abandon the Newtonian picture of the world as a machine that had emerged fully constructed from the hands of its Creator, and to replace it with the concept of an evolving and ever changing system". Capra is not saying the existence of God must be denied. He himself subscribes to the worldview that this author has dubbed "spiritual naturalism" (see last paragraph in this section). Capra says that the acceptance of macro-evolution calls for the abandonment of the biblical view of nature as exogenously designed and created with species distinctly different from one another. The biblical view of nature excludes only macro-evolution; it does not exclude microevolution.

With regard to humankind, macro-evolution brings humanity down to the level of animal - the animal with the highest intelligence. This became the accepted view not only in the biological sciences, but also in the budding human sciences of the nineteenth and twentieth centuries. After Darwin the early representatives of the humanities "held the view that man was no longer a person created in the image of God, but an elevated animal governed by drives and instincts. All that is essential in man was reduced, not to his relation to the Creator, but to his presumed origins from the animal kingdom" (Ouweneel, 1986:83).

The following evolutionary worldviews, relevant to the argument of this article, are discussed:

- Materialism: This worldview denies the existence of God. According to this worldview there is only the physical world driven by blind mechanical forces and life arose and evolved purely by chance. Materialism was appropriated by Western science and has been dubbed scientific materialism.

- Theistic evolutionism: This worldview maintains that an extracosmic God, not chance, directed the macro-evolutionary processes and God's method of progressive creation was either to use natural 
selection or to imbue original matter with a vital force that caused it to surge upwards slowly and inexorably to more and higher complexity (Wilder-Smith, 1974:167-168).

- Spiritual naturalism: This worldview upholds divine existence but not as an extracosmic reality. It ascribes to the cosmos the divine attributes of self-sufficiency and of being the source of all existence. Macro-evolution is ascribed to vitalism, that is, macro-evolution is the result of inherent psychic/spiritual properties of matter. This is an essentially pantheistic and/or animistic view in which "God is the organising matrix ... that which enlivens matter" (Ferguson, 1989: 420). This is also the religious position that materialists would arrive at if religion were to be refurbished from within the worldview of scientific materialism, because it too views the cosmos as self-sufficient and the source of all reality. Veneration of the cosmos, says Veith (1987:110), is illustrated in the rapt emotion and religious language of materialist scientists like Carl Sagan who claims: "The Cosmos is all there is, all there was, and all there ever will be." With these words, Sagan opened his television series, The Cosmos, produced in 1978.

Of the above worldviews materialism shall be discussed first.

\subsection{Materialism}

Materialism is a worldview that regards life as purely "an organised condition of matter" (Von Wahlert \& Von Wahlert cited in Gitt, 1993:77), and mind as "merely the highest product of matter" (Engels cited in Gitt 1993:48). Within the parameters of materialism, explanations of everything are restricted to natural causes only. Appropriated by science, science is defined as the human activity of seeking only natural explanations for what is observed in nature, which means that divine intervention in nature, also in abiogenesis and phylogenesis, is by definition excluded from science.

Materialism reduces the purpose of life to physical survival. It is a bleak philosophy and for many people ultimately intolerable. Humans do yearn for a deeper spiritual meaning to life. Such yearning revealed itself in the West's youthful counterculture of the 1960s and 1970s and in the interest in mysticism that is currently dispersed throughout Western culture. Materialism is thus rejected by many Westerners. However, most of these people have not rejected macro-evolution; they accept it as a scientifically proven fact.

Spirituality and a higher meaning to life are added to macro-evolution and the result is either theistic evolutionism or spiritual naturalism. Both these worldviews are not acknowledged by the scientific establishment. 


\subsection{Adding spirituality to the theory of evolution}

\subsubsection{Theistic evolutionism}

The example of theistic evolutionism that will be briefly reviewed in this article is that of Pierre Teilhard de Chardin (1881-1955), a Jesuit priest schooled in palaeontology. Teilhard de Chardin's ideas are present in and still inspire contemporary theistic evolutionists such as Denis Edwards (1999), John Haught (2000), Karl Schmitz-Moorman (1997) and Wentzel van Huysteen (1998). Theistic evolutionists proceed from the assumption that macro-evolution is a fact. As Schmitz-Moorman (1997: 16) puts it, macro-evolution "is the first concern when we consider essential changes in tools for theological reflection on God's creation".

In the fashion of all theistic evolutionists, Teilhard de Chardin (1955: $319 \mathrm{ff})$ first worked out his evolutionary theory and then fitted Christianity into it. The starting point was evolution: "Evolution is a light illuminating all facts, a curve that all lines must follow" (Teilhard de Chardin, 1955: 241). In contrast to materialism where evolution is without purpose and directed only by chance factors, Teilhard de Chardin held to the anthropic principle that the very thrust of evolution was the appearance of humankind (Fernando, 1983:29). Randomness was only apparent:

Beneath the apparent randomness of trial and error and natural selection there is a privileged axis, along which evolution is trying to move all the time - towards increasing complexity and consciousness. Man is the end-point which gives meaning to everything that went before (Fernando, 1983:28).

Teilhard de Chardin ascribed the upward direction of evolution to a Godcreated inherent psychic urge in matter that drives it inexorably forwards and upwards to greater physical complexity, life and consciousness. Teilhard de Chardin "believed that God made matter so that it was an algorithm of all life and order in the past, present and future" (WilderSmith, 1981a:223). The evolution of both physical complexity and consciousness reached a high point in human beings. With the breakthrough into humanity the noosphere (the mind-sphere - derived from the Greek word nous for mind) was added to the earth's biosphere (the layer of life on the surface of the earth) (Teilhard de Chardin, 1955:202). In the noosphere evolution occurred differently from the way it occurred in the biosphere. Changes in physical organisation ceased and humanity started to progress towards one unbroken "interthinking" whole, the final point of the whole evolutionary process, which he called the Omega Point (Teilhard de Chardin, 1955:266 ff). Teilhard (1955:322) added Christ to his theory by positing Him as both the inner "principle of vitality" as well as the Omega Point. 
Teilhard de Chardin added the concepts of Christianity to evolution, but the evolutionist and ecophilosopher Skolimowski (1983:60-61) maintains that evolutionary theory cannot accommodate orthodox Christianity:

There is profound incoherence in Teilhard's view of evolution: on the one hand, it is for him a forward unfolding process which culminates at Omega Point, at the end of time; and on the other hand, it is a process of going back to the original Christian God. By attempting to subsume Omega Point under Christian theology, Teilhard undermines the raison d'etre of evolution as an unfolding and self-actualising process ... [T]he Judeo-Christian tradition ... is based on the notion of Paradise Lost/Paradise Regained; ... If we recognise the notion and the authority of God as conceived in the traditional religions, particularly Christianity ... [w] hat we can do and the only thing we can do is to return to the Paradise Lost, to reacquire virtues that have been bestowed on us by God-the-Original-Maker ...

But there is a way of incorporating the Christo/Genesis into evolutionary design, namely by treating Christ not as God, as a point of final destiny and ultimate striving, but as a symbol, an inspiration, a reminder that even at that stage of our evolutionary development we are capable of so much grace and divinity. The Christ-consciousness becomes ... an imaginary flame that illumines our road towards greater grace and consciousness.

Skolimowski is not a Christian, but he acknowledges that macroevolution is logically inconsistent with the foundational theme of the Bible, that is Creation, Fall and Redemption. Skolimowski admits that macro-evolution can only logically accommodate the man Jesus as a prototype of human potentiality and the Christ as an idea, an inner principle that drives humanity upwards to higher states of spiritual consciousness.

Wilder-Smith (1974:167 ff) who is a Christian and a scientist - he has three doctorates in chemistry and pharmacology - also argues that the god of theistic evolutionism cannot be harmonised with the God of the Bible. He argues as follows: Macro-evolution, be it by chance or under divine direction, proceeds via struggle, suffering, pain, death and decay. It denies the weak, the ill or otherwise physically or psychically unfit an existence and favours instead the strong. Life certainly is like this, and the Bible ascribes it to man's fall into sin. However, the God of the Bible, who is one with Jesus Christ and who gave us the Sermon on the Mount, is not like this. The God of the Bible is a God of love, but He is also a God of judgement. He uses struggle, suffering, pain and death to punish sin, but He punishes righteously. He is a just God. He would never destroy those who are weak and sick for no fault of their own to create higher forms of life. The materialist molecular biologist, Jacques Monod, 
also argues that the Christian God would not use the destruction of the weak as a method of creation (cited in Ham,1997:74-76).

In the next section two theories of spiritual naturalism will be reviewed. They are James Lovelock's Gaia hypothesis and Rupert Sheldrake's theory of morphic fields.

\subsubsection{Spiritual naturalism}

\subsubsection{Lovelock's Gaia hypothesis}

Using the Greek name Gaia for the earth goddess, James Lovelock, an independent British scientist, presented the idea that the earth is alive. Lovelock (1979:11) defines Gaia as "a complex entity involving the Earth's biosphere, atmosphere, oceans and soil; the totality constituting a feedback or cybernetic system which seeks an optimal physical and chemical environment for life on this planet".

The Gaia hypothesis posits that the biosphere and the nonliving environment evolved, and are still in constant interaction in order to regulate suitable living conditions. Lovelock based the Gaia hypothesis on the fact that, contrary to other known planets, the earth has environmental conditions that allow life to flourish. The climate and the chemical compositions of the atmosphere (air), lithosphere (soil) and hydrosphere (oceans) are so finely tuned to support life that: "For this to have happened by chance is as unlikely as to survive unscathed a drive blindfold through rush-hour traffic" (Lovelock, 1991:15). Lovelock's argument is thus the age-old argument that a design points to a designer, but his designer is Gaia, the hypothetical interactive system between the biosphere and the nonliving environment itself.

\section{Gaia and Daisyworld}

The materialistic scientific establishment criticised Gaia as a vitalistic, teleological concept; "one that required foresight and planning by the biota [all living creatures]" (Lovelock, 1991:15). Lovelock's (1991:15 ff) response to this criticism was a computer model of Gaia which he called Daisyworld, a planet with the environment reduced to one variable, temperature, and the biosphere to one species, daisies in which light and dark varieties appear. Lovelock (1991:17-18) explains:

Imagine a time in the distant past of Daisyworld. The star that warms it was less luminous, so that only in the equatorial region was the mean temperature of bare ground warm enough, $5^{\circ} \mathrm{C}$, for growth. Here daisy seeds would slowly germinate and flower. Let us assume that in the first crop multicolored, light, and dark species were equally represented. Even before the first season's growth was over, the dark daisies would 
have been favored. Their greater absorption of sunlight in the localities where they grew would have warmed them above $5^{\circ} \mathrm{C}$. The lightcolored daisies would be at a disadvantage. Their white flowers would have faded and died because, reflecting the sunlight as they do, they would have cooled below the critical temperature of $5^{\circ} \mathrm{C}$.

The next season would see the dark daisies off to a head start, for their seeds would be the most abundant. Soon their presence would warm not just the plants themselves, but, as they grew and spread across the bare ground, would increase the temperature of the soil and air, at first locally and then regionally. With this rise of temperature, the rate of growth, the length of the warm season, and the spread of dark daisies would exert a positive feedback and lead to the colonization of most of the planet by dark daisies. The spread of dark daisies would eventually be limited by a rise of global temperature to levels above the optimum for growth. Any further spread of dark daisies would lead to a decline in seed production. In addition, when the global temperature is high, white daisies will grow and spread in competition with the dark ones. The growth and spread of white daisies is favored then because of their natural ability to keep cool.

As the star that shines on Daisyworld grows hotter and hotter, the proportion of dark to light daisies changes until, finally, the heat flux is so great that even the whitest daisy crop cannot keep enough of the planet below the critical $40^{\circ} \mathrm{C}$ upper limit for growth. At this time flower power is not enough. The planet becomes barren again, and so hot that there is no way for daisy life to start again.

From Lovelock's explanation of Daisyworld it is clear that the interaction between the biosphere and the environment can be envisaged without invoking biological foresight, planning or purpose. However, it has no link whatsoever with evolution. There is no evolution (macro or even micro) in Daisyworld. Daisyworld and its star are a created universe, conceived of in Lovelock's mind and manifested outside of his mind (on the computer screen). On Daisyworld, only repeated cycles of birth, growth and death take place within three fixed laws. These laws are: First, the star becomes progressively hotter; second, daisy life is limited to temperatures between $5^{\circ} \mathrm{C}$ and $40^{\circ} \mathrm{C}$; third, dark and light colours absorb and reflect heat respectively. On the planet life did not evolve. Its potential (daisy seeds) was present on the bare ground and no microevolutionary variations changed the colour of the daisies. All colours "were equally represented" in the first crop. Thereafter the dominant colour, dark or light, depended on the number of daisies of the same colour that survived the previous crop, "for their seeds would be the most abundant". In Lovelock's model the self-regulating dynamics of Daisyworld do nothing more than reflect the fixed laws which Lovelock designed into the system, and the model leaves his Gaia hypothesis as 
an explanation of macro-evolution unvalidated and, in fact, serves to support the idea of a Designer outside nature.

If the daisies in Daisyworld were sentient beings and effected a scientific search for a unifying principle they would eventually have found the lawful order that Lovelock programmed into Daisyworld, and they would have possibly believed both the order and the creator of the order to be endogenous to Daisyworld. To realise their error, the daisies would need to argue that an intelligent design requires an intelligent and exogenous designer.

Lovelock's acknowledgement of purpose and order in the world deserves praise. A world without purpose is a joyless world. Darwin himself, when approaching ultimate death, admitted in his writings that on the basis of his theory he had lost his joy in the arts and in nature (Alexander, 1972: 106; Schaeffer, 1970:9).

In the next section Sheldrake's theory of morphic fields will be analysed.

\subsubsection{Sheldrake's theory of morphic fields}

Rupert Sheldrake is a biologist who did research work on plant physiology in India. Sheldrake is a self-admitted animist. He proposes that morphic fields (analogous to electric and magnetic fields) surround all systems (living and nonliving) and that these fields govern macroevolution. Sheldrake (1990:82) derived the term "morphic" from the Greek word morphe meaning "form".

In support of his theory Sheldrake (1990:82) appealed to biologists in the 1920s who discovered that some plants and animals can regenerate their form from a portion of the "mother" plant or animal. Purposive tendencies are also revealed in the instinctual behaviour of the animal world (Sheldrake, 1990:90 ff). Such tendencies cannot be explained by purposeless, mechanical forces, but point to an intelligent plan which, although anathema to materialists, reinstates the argument from design to Designer. However, Sheldrake (like Lovelock) seeks both plan and planner solely in the natural world. Sheldrake explains nature's purposive tendencies in terms of his animistic, cosmos-bound spirituality but translated into scientific terminology. Morphic fields and the vibratory frequencies of morphic resonance assume the roles that ancient animism ascribed to inner spiritual powers.

Sheldrake (1990:88) postulates that "self-organizing systems at all levels of complexity, including molecules, crystals, cells, tissues, organisms and societies of organisms are organized by fields called 'morphic fields'. Morphogenetic fields are just one type of morphic field, those concerned 
with the development and maintenance of bodies of organisms". Morphic fields are of "an intrinsically evolutionary nature ... a kind of collective memory on which each member of the species draws, and to which it in turn contributes" (Sheldrake, 1990:88). Information is transferred from past to present members of a species through morphic resonance, the influence of which, Sheldrake (1990:88-89) claims, determines the characteristic form and behaviour of the species and should, furthermore, be understood probabilistically as evolving habits and not as fixed and predetermined. In other words, Sheldrake attributes the regularity of biological form and behaviour to morphic fields which are never fixed but always subject to evolutionary change and complexification.

\section{Sheldrake's evidence of morphic fields}

\section{- A new morphic field has to come into existence}

Sheldrake (1990:89 ff) provides three examples of evidence which he alleges is in favour of his hypothesis of morphic fields. Two relate to form and one relates to behaviour. Sheldrake's (1990:89) first example related to form is as follows:

[W]hen a newly synthesised organic chemical is crystallized for the first time - say a new drug - there will be no morphic resonance from previous crystals of this type. A new morphic field has to come into existence ... The next time the substance is crystallized anywhere in the world, morphic resonance from the first crystals will make this same pattern of crystallization more probable ...

The existence of a morphic field and its resonance is, however, pure speculation whilst his reference to the synthesis of a new chemical compound is actually a contradiction of his metaphysical position, namely that nature is its own designer. It serves rather to support the supernaturalist position of a Designer outside nature: The scientist who synthesised the new chemical compound applied his exogenous mental plan to the ordering of the constituent chemicals. The origin of the new chemical compound is the scientist's exogenous intelligence that ordered the constituent chemicals in the correct way (cf. Wilder-Smith, 1981a:25 ff, 1975:55 ff).

\section{- Certain abnormalities become more likely}

The other example that Sheldrake (1990:90) supplies with regard to form is that experiments on fruit flies have shown that certain abnormalities become more likely once such an abnormality has appeared in one member of a species. This, however, demonstrates only microevolutionary changes and such changes are heritable. The abnormal fruit flies did not undergo macro-evolution to become a totally different species. Macro-evolution would require that new information be added to 
the existing genetic code, which biologists have ascertained does not happen. Natural selection, random genetic drift and laboratorymanipulation can act only on existing genetic information and cause only variations within a species (Ackerman \& Williams, 1999:51, 82). Whether new genetic information could be added in the past, which is what macro-evolution requires, is a matter of hypothetical speculation. Sheldrake believes that the addition of new genetic information occurred in the past and could even still occur because of the vitalistic changeability of the morphic fields that supposedly govern genetic behaviour. Nevertheless, his argument for the existence of such fields is faulty; when his example is debated in the light of validated knowledge about genetic behaviour, it actually stresses phylic stability (Smith, 1992:56-57).

\section{- Morphic fields are a collective but changeable memory bank}

Sheldrake (1990:91) gives another example, related to behaviour, to support his idea of morphic fields as a collective but always changeable memory bank. He claims that when one group of rats learnt new behaviour, other rats showed a tendency to learn the new behaviour faster. But the house training of puppies clearly refutes the notion of an evolving memory bank. Even if it did exist for some behavioural aspects of some species, one still struggles to understand why behaviour at the deepest instinctual level (such as that of a female mud wasp who always builds her nest in the same way) is viewed by Sheldrake (1990:90-91) as merely a habit attributable to the collective power of morphic resonance and not a given law of nature.

\section{- Morphic determinism and morphic freedom}

Light is thrown on Sheldrake's reasoning by the way in which he resolves the conflict in his system between morphic determinism and morphic freedom. Sheldrake (1990:90-91) regards the instinctual behaviour of a species as "a fixed action pattern" predetermined by morphic resonance. This, Sheldrake (1990:104) says, is a habit, the continual repetition of which gives it the appearance of a law, which means that future members of a species have the freedom to change inherited morphic fields in the same way that humans can change inherited character traits by an act of will. Motivated by his belief in animism, Sheldrake anthropomorphises nature to the extent that human freedom of will is projected on to nature. However, anthropomorphism of nature, as Francis Schaeffer (1970:25) points out, is an evasion of the reality of nature. It endows nature with characteristics it does not possess and ignores its real characteristics.

Sheldrake (1990:109) criticises the idea of fixed laws because "[t]he designing mind of ... God [as Creator] is still there in the background". 
Flying in the face of scientific evidence, Sheldrake (1990:103) maintains that "[t]he idea of the laws of nature is based on a political metaphor. Just as human societies are governed by laws, so the whole of nature is supposedly ruled by the laws of nature". Sheldrake is in fact echoing Alfred North Whitehead (cited in Jaki, 1989:20) who also denied the idea of natural laws. The criticism of this view by the physicist and historian of science, Prof. Stanley Jaki (1989:19-20), is scathing: "Such a view had little room for exact science but plenty for unbridled fantasies ... Whitehead never explained how science ... can be cultivated on that very 'temporary' basis."

Sheldrake (1990:102) regards the acknowledgement of natural laws as an outdated way of thinking which "bears a strong resemblance to the Christian theology of creation by the word or logos of God". Fixed laws and macro-evolution are correctly accepted by Sheldrake (1990:103) as logical contradictions: "If all nature evolves, why should the laws of nature not evolve as well? Why should we go on assuming that they are eternally fixed?"

In a book which is documented with great detail and grounded in a keen understanding of science (ancient and modern) and cultural philosophies (ancient and modern), Jaki (1974:vii) indicates that:

Great cultures where the scientific enterprise came to a standstill, invariably failed to formulate the notion of physical law, or the law of nature. Theirs was a theology with no belief in a personal, rational, absolutely transcendent Lawgiver, or Creator. Their cosmology reflected a pantheistic and animistic view of nature caught in the treadmill of perennial, inexorable returns. The scientific quest found fertile soil when this faith in a personal, rational Creator had truly permeated a whole culture, beginning with the centuries of the High Middle Ages. It was that faith which provided, in sufficient measure, confidence in the rationality of the universe, trust in progress, and appreciation of the quantitative method, all indispensable ingredients of the scientific quest.

Jaki (1974:356) points out that there is in our time "a steadily growing realization that the man of science, no less that his counterpart in religion, lives ultimately by faith". As people of faith, scientists are, according to both Jaki (1974:356 ff) and Sheldrake (1990:102 ff), faced with two foundational alternatives - confidence in a law-abiding universe, a confidence in which empirical, exact science flourished, but which by its very nature, as Sheldrake (1990:102) recognises, implies "creation by the word or logos of God", or the acceptance of the full implications of an evolving universe where all orderliness is dissolved in a state of perpetual flux, and purpose is sought in "pantheism and immanentism" (Jaki, 1974:356). 


\section{Conclusion}

Evolution as a paradigm for education would mean that the theory of evolution as the explanation of the origin of the universe and the life it contains, and its concomitant worldviews, would be taught exclusively and, inevitably, as the assured, incontrovertible conclusion of science, which it is not. Leonard Brand (1997), a biologist, Werner Gitt (1997), an information scientist, and Hugh Ross (2001), an astrophysicist, are among the contemporary natural scientists who use up-to-date scientific evidence to build a compelling case for the biblical worldview. Intellectual honesty demands that students also be presented with this alternative logical interpretation of scientific data which have a bearing on the question of the origin of the universe and the life it contains. The metaphysical nature of the theory of evolution should be acknowledged.

\section{Bibliography}

ACKERMAN, P. \& WILLIAMS, B. 1999. Kansas tornado: 1999 science curriculum standards battle. El Cajon, CA : Institute for Creation Research.

ALEXANDER, D. 1972. Beyond science. Berkhamsted, Herts : Lion.

BRAND, L. 1997. Faith, reason, and earth history. Berrien Springs, Mich. : Andrews University.

BROWN, C. 1968. Philosophy and the Christian faith: a historical sketch from the Middle Ages to the present day. Downers Grove, III. : InterVarsity.

CLOETE, T.E. 2000. Genetic perspectives on the origin of life. Tydskrif vir Christelike Wetenskap, 36(3 \& 4):39-54.

CAPRA, F. 1990. The turning point: science, society and the rising culture. London : Fontana Paperbacks.

DENTON, M. 1987. Evolution: a theory in crisis. Bethesda, Maryland : Adler \& Adler.

EDWARDS, D. 1999. The god of evolution. New York : Paulist.

FERGUSON, M. 1989. The Aquarian conspiracy: personal and social transformation in the 1980s. London : Paladin.

FERNANDO, M. 1983. Pierre Teilhard de Chardin: an outline of his thought on the history and future of mankind. (In Zonneveld, L. \& Muller, R., eds. The desire to be human: a global reconnaissance of human perspectives in an age of transformation written in honour of Pierre Teilhard de Chardin. Wassenaar, Netherlands : Mirananda. p. 26-37.)

FRAIR, W. \& DAVIS, P. 1983. A case for creation. 3rd revised edition. Chicago : Moody.

GITT, W. 1993. Did God use evolution? Bielefeld, Germany : Christliche LiteraturVerbreitung.

GITT, W. 1997. In the beginning was information. Bielefeld, Germany : Christliche Literatur-Verbreitung.

GOERTZ, D. 1990. Transcendental typology. Shippensburg, Pa. : Destiny Image.

GOSLING, M. 2000. Many varsity students have never heard of Darwin's evolution theory. Pretoria News, June, 10.

HAM, K. 1997. The lie: evolution. Green Forest, Australia : Master.

HAUGHT, J.F. 2000. God after Darwin: a theology of evolution. Boulder, Colorado : Westview. 
HOLBROOK, D. 1987. Evolution and the humanities. Aldershot, Hampshire : Gower.

HOOVER, A.J. 1988. Evolution and the ways of science. (In Thomas, J.D., ed. Evolution and faith. Abilene, Texas: Abilene Christian University. p. 9-25.)

JAKI, S. 1974. Science and creation. Edinburgh : Scottish Academic.

JAKI, S. 1989. God and the cosmologists. Edinburgh : Scottish Academic.

KLEIN, S. 1988. Preface. (In Sunderland L.D. Darwin's enigma: Fossils and other problems. 4th revised edition. Santee, Calif. : Master. p. 5-6.)

LOVEJOY, A.O. 1942. The great chain of being: a study of the history of an idea. Cambridge, Mass. : Harvard University.

LOVELOCK, J. 1979. Gaia: a new look at life on earth. Oxford : Oxford University.

LOVELOCK, J. 1991. Mother Earth: myth or science. (In Barlow, C., ed. From Gaia to selfish genes: selected writings in the life sciences. Cambridge, Mass. : MIT. p. 319.)

MOHR, H.1989. Is the program of molecular biology reductionistic? (In HoyningenHuene, P. \& Wuketits, F.M., eds. Reductionism and systems theory in the life sciences: Some problems and perspectives. Dordrecht : Kluwer Academic. p. 137-159.)

MORRIS, H.M. 1989. The long war against God: the history and impact of the creation/evolution debate. Grand Rapids, Mich. : Baker.

OUWENEEL, W.J. 1986. Evolution and the humanities. (In Andrews, E., Gitt, W. \& Ouweneel, W.J., eds. Concepts in creationism. Welwyn, Herts : Evangelical Press. p. 81-108.)

PARKER, G.E. 1987. The fossil evidence. (In Morris, H.M. \& Parker, G.E. What is creation science? Revised and expanded edition. El Cajon, CA. : Master. p. 125184.)

ROSS, H. 2001. The Creator and the cosmos: how the greatest discoveries of the century reveal God. 3rd expanded edition. Colorado Springs : Navpress.

SCHAEFFER, F. 1970. Pollution and the death of man: the Christian view of ecology. London : Hodder \& Stoughton.

SCHMITZ-MOORMAN, K. 1997. Theology of creation in an evolutionary world. Cleveland : Pilgrim.

SHELDRAKE, R. 1990. The rebirth of nature: the greening of science and God. London : Century.

SKOLIMOWSKI, H. 1983. Evolutionary illuminations. (In Zonneveld, L. \& Muller, R., eds. The desire to be human: a global reconnaissance of human perspectives in an age of transformation written in honour of Pierre Teilhard de Chardin. Wassenaar, Netherlands : Mirananda. p. 54-67.)

SMITH, J.W. 1992. The recent case against physicalist theories of mind: a review essay. (In Lamb, D., ed. New horizons in the philosophy of science. Aldershot, Hampshire : Avebury. p. 49-65.)

STROMBERG, R.N. 1966. An intellectual history of modern Europe. New York : Appleton-Century-Crofts.

SUNDERLAND, L.D. 1988. Darwin's enigma: Fossils and other problems. 4th revised edition. Santee, California : Master.

TEILHARD de CHARDIN, P. 1955. The phenomenon of man. (Translated by B. Wall.) London : Collins.

VAN HUYSTEEN, W. 1998. Duet or duel? Theology and science in a postmodern world. Harrisburg, Pa. : Trinity.

VEITH, G.A. 1987. Loving God with all your mind: how to survive and prosper as a Christian in the secular university and post-Christian culture. Westchester, III : Crossway. 
WILDER-SMITH, A.E. 1974. Man's origin, man's destiny. Stuttgart : Hänssler.

WILDER-SMITH, A.E. 1975. God: to be or not to be: a critical analysis of Monod's scientific materialism. Stuttgart : Hänssler.

WILDER-SMITH, A.E. 1981a. The creation of life: a cybernetic approach to evolution. San Diego : Master.

WILDER-SMITH, A.E. 1981b. The natural sciences know nothing of evolution. San Diego : Master.

\section{Key concepts:}

macro-evolution

materialism

spiritual naturalism (pantheism and animism)

theistic evolutionism

\section{Kernbegrippe:}

geestelike naturalisme (panteïsme en animisme)

makroevolusie

materialisme

teïstiese evolusionisme 
